\title{
PEDIATRIC ISOLATED OCULOMOTOR NERVE SCHWANNOMA: A RARE CASE REPORT
}

Sundip Shenoy ${ }^{1}$, Anitha S. Maiya², R. Jayaram³ ${ }^{3}$ Anyatama Chakravarty ${ }^{4}$, Basavaraj Zalaki ${ }^{5}$

\section{HOW TO CITE THIS ARTICLE:}

Sundip Shenoy, Anitha S. Maiya, R. Jayaram, Anyatama Chakravarty, Basavaraj Zalaki. "Pediatric Isolated Oculomotor Nerve Schwannoma: A Rare Case Report". Journal of Evolution of Medical and Dental Sciences 2014; Vol. 3, Issue 06, February 10; Page: 1385-1393, DOI: 10.14260/jemds/2014/1996

\begin{abstract}
Schwannomas constitute about 8\% of all intracranial tumors and commonly arise from the vestibulocochlear and trigeminal nerves. Motor nerve schwannomas arising from the oculomotor nerve are very rare. Currently, there are approximately 38 well-documented cases of isolated oculomotor nerve schwannoma reported in the literature worldwide. The management of these large tumors is especially challenging given the proximity of these tumors to the cranial nerves and the brainstem. This article presents a 10-year-old girl with isolated cisternal oculomotor nerve schwannoma causing parent nerve dysfunction.
\end{abstract}

KEYWORDS: Oculomotor Palsy, Schwannomma, Paralytic Squint.

INTRODUCTION: Schwannomas are benign peripheral nerve sheath tumors. They constitute about $8 \%$ of all intracranial tumors and have a great predilection to arise from sensory nerves ${ }^{1}$. Motor nerve schwannomas arising from the oculomotor nerve are very rare. Thirty-eight cases of solitary oculomotor schwannoma reported in the literature include 15 male and 23 female patients, whose age range from 8 to 74 years. The tumor was located in the orbit in four cases (solitary orbital type), in the subarachnoid space in 17 cases (cisternal type), in the cavernous sinus in 12 cases (cavernous type), extending from the cavernous sinus to the cistern in five cases (cisternocavernous type). ${ }^{2-4}$ Currently, only 13 children with oculomotor nerve schwannoma without neurofibromatosis have been sufficiently documented. ${ }^{5}$

CASE REPORT: A 10 year old school going girl, with history of chronic headache of 1 year duration presented to our Dept. Of Ophthalmology OPD, with history of sudden onset of double vision, ptosis and inability to move the right eye since 7 days. Patient was evaluated as regards to etiology, which was negative for trauma, infection, inflammation and demyelinating, dystrophy, congenital syndromes or systemic diseases. Patient underwent detailed examination, medical, neurological and ocular and the following observations were made.

CHIEF COMPLAINTS: H/o dull aching headache since 1yr. C/o double vision with drooping of eyelids since seven days.

- Precipitating causes: no h/o fever, whooping cough, measles, patching, amblyopia treatment or food poisoning

- No h/o projectile vomiting.

- No h/o trauma.

- Patient conscious, cooperative and oriented with respect to time, place and person.

- GENERAL EXAMINATION: Pulse $=80 / \mathrm{min} \mathrm{BP}=120 / 80 \mathrm{~mm}$ of $\mathrm{Hg}$

- SYSTEMIC EXAMINATION: Unremarkable, 
- OCULAR EXAMINATION and SQUINT INVESTIGATION:

- Old photographs were normal

- Head posture: normal

- Ocular posture: atonic proptosis absent, deflected outward and rotated internally, reflecting intact IVth and VIth nerve function. (Photo-1)

- Cover test: reveals Exotropia (right eye)

- Secondary deviation greater than primary deviation indicating paralytic squint of right eye. (Photo-2)

- EOM: Extra ocular movements (Photo-3)

Adduction defective in left gaze (revealing right medial rectus palsy).

Elevation defective in upgaze both in abduction and adduction (revealing right superior rectus and right inferior oblique palsy).

Down gaze limitation of right eye (revealing right inferior rectus palsy).

Intact abduction of the right eye. (Revealing intact right lateral rectus function).

Intact intorsion (noting the position of conjunctival vessels) of right eye revealing intact right superior oblique.

- Bruckner test: Right eye brighter (fundal glow)

- Anterior segment: partial ptosis right eye

- Mid-dilated pupil, sluggishly reacting to light right eye

- Posterior segment: normal

- No papilledema

- $\mathrm{V}_{\mathrm{A}}: 6 / 6 \mathrm{OU}$

- Hirschberg's test: 30 degree right exodeviation

- Past pointing present

- Diplopia charting: showed binocular heteronymous crossed diplopia with false image higher with upper end tilted towards paralysed side

- Worth's four dot test:5 dots seen revealing heteronymous diplopia

- Abnormal receding of near point

- Reduced range of accommodation of right eye showing paralysis of accommodation.

- Force duction test: negative

- Other Neurological evaluation/ other cranial nerves/ sensory and motor system intact/No other deficit noted other than $3^{\text {rd }}$ cranial nerve palsy.

\section{MRI:}

Iso intense to brain parenchyma in T1 weighted images.

Hypo intense in $\mathrm{T} 2$ weighted images.

Contrast study with I V Gadolinium results in intense enhancement of the tumor, suggestive schwannoma showing a dimension of $7.5 \times 5.1 \times 4.8$ (AP $\times$ T x CC) $\mathrm{mm}$ located along the long axis of the proximal most part of the cisternal segment of the R oculomotor Nerve. The lesion abuts the right PCA and right side of midbrain. 
DIAGNOSIS: Right sided acquired incomplete, pupil involving, isolated oculomotor nerve palsy due to tumor (schwannoma) in the cisternal part of the nerve.

DISCUSSION: Isolated oculomotor nerve schwannoma without neurofibromatosis is uncommon, with only about 38 documented patients, most of whom are adults. ${ }^{6}$ Oculomotor nerve schwannoma is exceptionally rare in children with only 13 cases reported so far. ${ }^{7}$

Including our patient, there have been six male and eight female patients, ranging in age from 15 months to 16 years, with a mean age of 9.1 years. The maximal diameters of the tumors ranged from $4 \mathrm{~mm}$ to $55 \mathrm{~mm}$, with an average size of $19.5 \mathrm{~mm}$. Among those cases where clinical history was known, the duration of preoperative symptoms and signs lasted from 2 weeks to 12 years with a subacute or chronic onset fashion. Oculomotor nerve paresis was the most common neurological sign in this cohort of patients. ${ }^{7}$

Review data of children-related isolated oculomotor nerve schwannoma in literature are summarized in Table $1 .^{7}$

In our case, the probable diagnosis of Oculomotor nerve Schwannoma was arrived based on features of oculomotor paresis, tumor location along the course of the oculomotor nerve and classic MRI features. Differential Diagnosis of the tumors of Oculomotor nerve with MRI characteristic features is described in Table 2.

Total removal of schwannoma usually results in severe postoperative parent nerve paresis. Various neuro surgical interventions like Pterion approach with post-operative stereo tactic radiotherapy may lead to rescue of the patient. Surgical treatment is indicated only for large tumors that present in association with consciousness disturbance, other cranial nerve signs, or hemiparesis due to mass effect, or in cases where the lesion shows malignant features with rapid enlargement. Close observation is recommended in asymptomatic cases or for tumors $<10 \mathrm{~mm}$. Histopathologic findings as described in literature are, it shows two types of patterns of growth. In Antoni A type growth, elongated cells with cytoplasmic processes are arranged in fascicles in areas of moderate to high cellularity with little stroma with Verocay bodies. In Antoni B pattern of growth, the tumor is less densely cellular with loose meshwork of cells along with microcysts and myxoid changes.

\begin{tabular}{|c|c|c|c|c|c|c|}
\hline $\begin{array}{l}\text { Case } \\
\text { No. }\end{array}$ & $\begin{array}{c}\text { Author (Year) } \\
\text { [Ref.] }\end{array}$ & $\begin{array}{c}\text { Age(years)/ } \\
\text { Sex }\end{array}$ & $\begin{array}{l}\text { Duration of } \\
\text { symptoms }\end{array}$ & $\begin{array}{c}\text { Signs and } \\
\text { symptoms }\end{array}$ & $\begin{array}{l}\text { Location of } \\
\text { the tumor }\end{array}$ & $\begin{array}{c}\text { Tumor } \\
\text { size }(\mathrm{mm})\end{array}$ \\
\hline 1 & Sener $(2006)^{8}$ & $2 / \mathrm{M}$ & $\begin{array}{c}\text { Not } \\
\text { described }\end{array}$ & Ptosis & Cisternal & 30 \\
\hline 2 & $\begin{array}{l}\text { Chewning et } \\
\text { al. }(2008)^{1}\end{array}$ & $3 / \mathrm{F}$ & 2 weeks & Headache, ptosis & Cisternal & 4 \\
\hline 3 & $\begin{array}{c}\text { Bejjani et al. } \\
(1997)^{9}\end{array}$ & $6 / F$ & 3 months & $\begin{array}{c}\text { Oculomotor } \\
\text { nerve paralysis, } \\
\text { hemiparesis }\end{array}$ & Cisterna & 12 \\
\hline 4 & $\begin{array}{l}\text { Mariniello et } \\
\text { al. }(1999)^{10}\end{array}$ & $8 / \mathrm{F}$ & 8 years & Diplopia, ptosis & Cavernous & 15 \\
\hline 5 & $\begin{array}{c}\text { Kozic et al. } \\
(2006)^{11}\end{array}$ & $9 / \mathrm{M}$ & $\begin{array}{c}\text { Not } \\
\text { described }\end{array}$ & $\begin{array}{c}\text { Ptosis, } \\
\text { hemiparesis }\end{array}$ & $\begin{array}{l}\text { Cisterno- } \\
\text { cavernous }\end{array}$ & 27 \\
\hline
\end{tabular}




\begin{tabular}{|c|c|c|c|c|c|c|}
\hline 6 & $\begin{array}{l}\text { Leunda et al. } \\
\qquad(1982)^{12}\end{array}$ & $11 / \mathrm{M}$ & 3 months & $\begin{array}{c}\text { Oculomotor } \\
\text { nerve paralysis, } \\
\text { hemiparesis }\end{array}$ & $\begin{array}{l}\text { Cisterno- } \\
\text { cavernous }\end{array}$ & 55 \\
\hline 7 & $\begin{array}{l}\text { Muhammad et } \\
\text { al. }(2008)^{5}\end{array}$ & $11 / F$ & 3 years & $\begin{array}{c}\text { Oculomotor } \\
\text { nerve paralysis, } \\
\text { exorbitism }\end{array}$ & Intraorbital & $\begin{array}{c}\text { Not } \\
\text { described }\end{array}$ \\
\hline 8 & $\begin{array}{l}\text { Murakami et } \\
\text { al. }(2005)^{13}\end{array}$ & $11 / \mathrm{F}$ & 5 years & $\begin{array}{l}\text { Headache, } \\
\text { diplopia }\end{array}$ & Cisternal & 5 \\
\hline 9 & $\begin{array}{l}\text { Netuka and } \\
\text { Benes } \\
(2003)^{14}\end{array}$ & $12 / F$ & 10 years & $\begin{array}{c}\text { Headache, cheek } \\
\text { paraesthesia }\end{array}$ & $\begin{array}{l}\text { Cisterno- } \\
\text { cavernous }\end{array}$ & 28 \\
\hline 10 & $\begin{array}{l}\text { Niazi and } \\
\text { Boggan } \\
(1994)^{15}\end{array}$ & $13 / \mathrm{M}$ & 2 weeks & $\begin{array}{c}\text { Ptosis, } \\
\text { hemiparesis }\end{array}$ & $\begin{array}{l}\text { Cisterno- } \\
\text { cavernous }\end{array}$ & 30 \\
\hline 11 & $\begin{array}{l}\text { Bisdorff and } \\
\text { Wildanger } \\
(2006)^{16}\end{array}$ & $14 / F$ & 12 years & $\begin{array}{c}\text { Headache, } \\
\text { diplopia, ptosis }\end{array}$ & Cisternal & 7 \\
\hline 12 & $\begin{array}{l}\text { Kansu et al. } \\
(1982)^{17}\end{array}$ & $15 / \mathrm{M}$ & 11 years & $\begin{array}{c}\text { Oculomotor } \\
\text { nerve paralysis }\end{array}$ & Cisternal & 4 \\
\hline 13 & $\begin{array}{l}\text { S S Yang et al } \\
(2013)^{7}\end{array}$ & $3 / \mathrm{M}$ & 2 weeks & Ptosis, irritability & Cisternal & 13 \\
\hline 14 & $\begin{array}{l}\text { PRESENT } \\
\text { CASE }\end{array}$ & $10 / F$ & $\begin{array}{l}\text { 1year------ } \\
\text { 1week----- }\end{array}$ & $\begin{array}{c}\text { Headache, } \\
\text { diplopia, EOM } \\
\text { palsy, ptosis. }\end{array}$ & Cisternal & 7.5 \\
\hline
\end{tabular}

\begin{tabular}{|l|l|}
\hline \multicolumn{1}{|c|}{ TUMOURS } & \multicolumn{1}{c|}{ MRI Characteristics } \\
\hline 1. Schwannoma & $\begin{array}{l}\text { Homogenous masses typically isointense or slightly hypointense relative } \\
\text { to gray matter on T1- weighted images and slightly hypointense to CSF on } \\
\text { T2- weighted images. }\end{array}$ \\
\hline 2. Meningioma & $\begin{array}{l}\text { It is typically a homogenous markedly enhanced extra-axial mass. } \\
\text { Hyperintensity on T2-weighted images indicates soft-tumor consistency } \\
\text { and microhypervascularity. Low-intensity portions of the tumour on T2- } \\
\text { weighted images indicate more fibrous fibroblastic meningiomas, } \\
\text { whereas higher intensity portions indicate a softer angioblastic tumor. }\end{array}$ \\
\hline 3. Astrocytoma & $\begin{array}{l}\text { Astrocytomas are typically inhomogenous hyperintense on T2-weighted } \\
\text { images. On T1- weighted images, astrocytomas are hypointense relative } \\
\text { to white matter. Contrast enhancement may be absent or mild. }\end{array}$ \\
\hline 4. Sarcoma & $\begin{array}{l}\text { Sarcomas appear hypointense to muscle on T1-weighted images and } \\
\text { hyperintense on T2-weighted images. }\end{array}$ \\
\hline
\end{tabular}




\section{CASE REPORT}

\begin{tabular}{|c|c|}
\hline 5. Pituitary adenoma & $\begin{array}{l}\text { Pituitary microadenomas are usually slightly hypointense to isointense to } \\
\text { the gray matter on T1-weighted images and range from isointense to } \\
\text { hyperintense on T2-weighted images unless they contain intratumoural } \\
\text { hemorrhage or cystic changes. }\end{array}$ \\
\hline 6. Craniopharyngiomas & $\begin{array}{l}\text { On MRI, the adamantinomatous subtype appears as a predominately } \\
\text { cystic suprasellar mass with a solid component. Cystic areas appear } \\
\text { hyperintense on } \mathrm{T} 1 \text { and } \mathrm{T} 2 \text {-weighted images with heterogeneous } \\
\text { isointense to hypointense solid components. }\end{array}$ \\
\hline 7. Epidermoid cyst & $\begin{array}{l}\text { On T1-weigthed images these lesions are generally slightly hypointense } \\
\text { or isointense to relative gray matter. The lesions are usually isointense } \\
\text { relative to CSF on T2-weighted images, but they may be slightly } \\
\text { hyperintense. }\end{array}$ \\
\hline 8. Arachnoid cyst & $\begin{array}{l}\text { On MRI, arachnoid cysts appear as well-defined nonenhancing } \\
\text { intracranial masses that are isointense to CSF. Diagnostic confusion } \\
\text { occasionally arises between arachnoid cysts and epidermoid cysts. The } 2 \\
\text { masses may have similar characteristics on T1-weighted and T2- } \\
\text { weighted images, and neither shows enhancement with gadolinium. } \\
\text { However, arachnoid cysts follow CSF signals on all sequences-in } \\
\text { particular, on the FLAIR sequence-in contradistinction to epidermoid } \\
\text { cysts. DWIs allow easier differentiation of the } 2 \text { masses. }\end{array}$ \\
\hline 9. Teratoid tumours & $\begin{array}{l}\text { On T2-weighted images the dominant signal intensity of the soild } \\
\text { component of the tumour is assessed in comparison with cortical or deep } \\
\text { gray matter as isointense or hyperintense. }\end{array}$ \\
\hline $\begin{array}{l}\text { 10. Cavernous } \\
\text { haemangioma }\end{array}$ & $\begin{array}{l}\text { Acute haemangioma containing deoxyhemoglobin is isointense on T1- } \\
\text { weighted images and markedly hypointense on T2-weighted images. } \\
\text { Subacute hematoma, which contains extracellular methemoglobin, } \\
\text { displays hyperintensity on both T1- and T2-weighted images because of } \\
\text { the paramagnetic effect of the methemoglobin. Smaller cavernomas may } \\
\text { appear as focal hypointense nodules with T1- and T2-weighted } \\
\text { sequences. }\end{array}$ \\
\hline
\end{tabular}

TREATMENT: While small asymptomatic tumors need to be observed, present tumor described (schwannoma) which is symptomatic showing ocular manifestations may need neurosurgical interventions and post-operative stereotactic radiotherapy. Presently the patient is being followed up regularly at Depts. of Neurosurgery and Ophthalmology.

SUMMARY: We have presented a 10 year old school going girl presenting with long standing headache (of 1 year duration) and acute onset diplopia with partial ptosis of recent onset (7 days). A diagnosis of isolated oculomotor nerve paresis due to intracranial space occupying lesion (oculomotor nerve schwannoma) was made, which is a rarity. Considering the school going age of the child, one needs to factor in psychosocial impact of the disfiguring aspect of paralytic squint. Meticulous clinical examination and MRI when used judiciously clinches the diagnosis of the tumour. 
The child needs to undergo frequent follow ups with Ophthalmologists and Neurosurgeons at our institute. Regarding treatment, it has to be individualized as there is no uniform accepted modality till this date.

CONCLUSION: We have presented the $14^{\text {th }}$ case of pediatric isolated oculomotor nerve schwannoma with ocular manifestations without neurofibromatosis, which is a rarity. Indications for surgical excision of the tumour is yet to be established as surgical intervention leads to high incidence of total third nerve palsy, and its attendant co morbidity. Improvement in the diagnostic imaging like MRI, increases the likelihood of the detection of the tumor(schwannoma) as chronic headache may mimic ophthalmoplegic migraine.

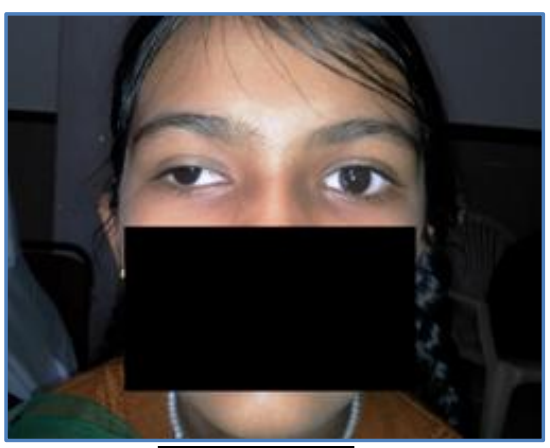

Photo 1

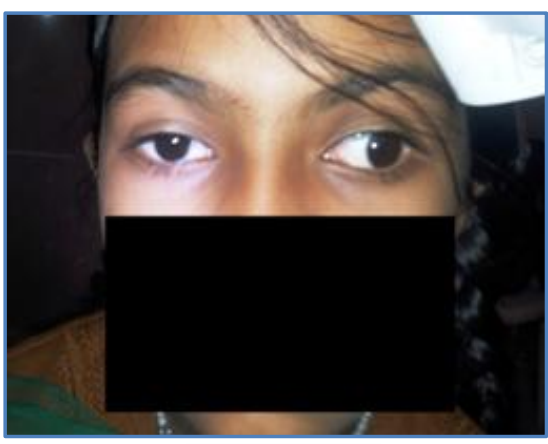

Photo 2

PHOTO 1: Primary position of gaze showing Incomplete pupil involving isolated Oculomotor nerve palsy in the right eye with partial ptosis.

PHOTO 2: Secondary deviation in the non paretic left eye greater than primary deviation in the paretic right eye indicating paralytic non concomitant squint of right eye.

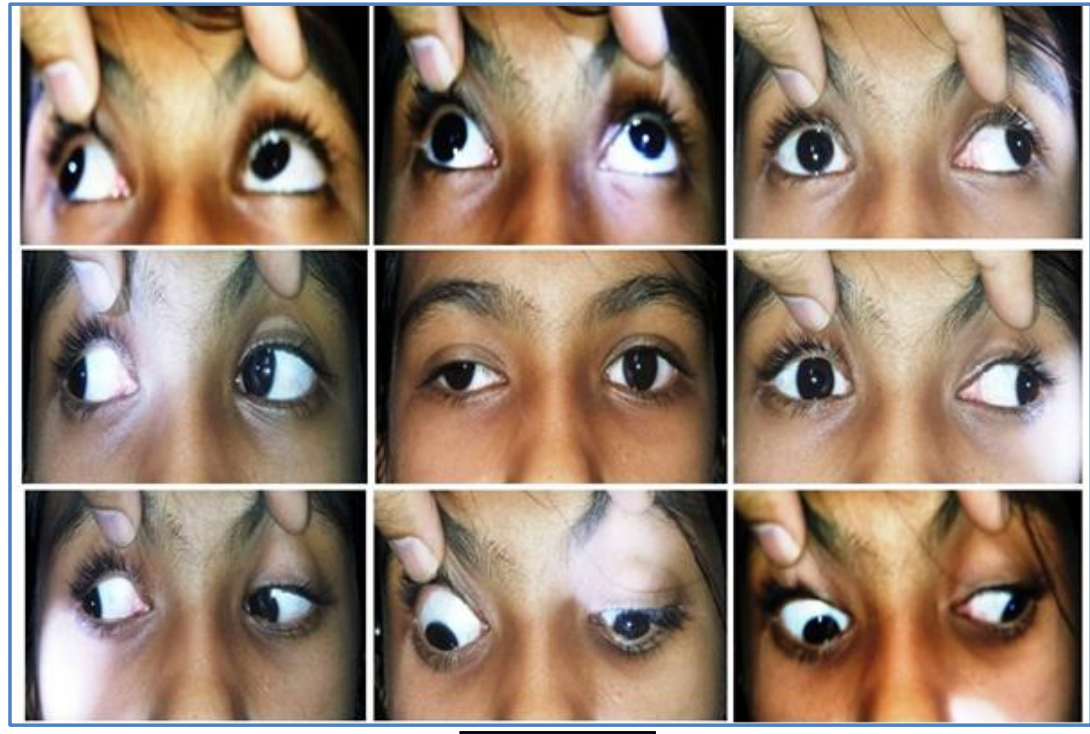

Photo 3 
PHOT0 3: Showing eye positions in the nine cardinal gaze positions with restriction of movements in adduction (medial rectus palsy), elevation (superior rectus and inferior oblique palsy) and depression (down and out-inferior rectus palsy) of the right eye.

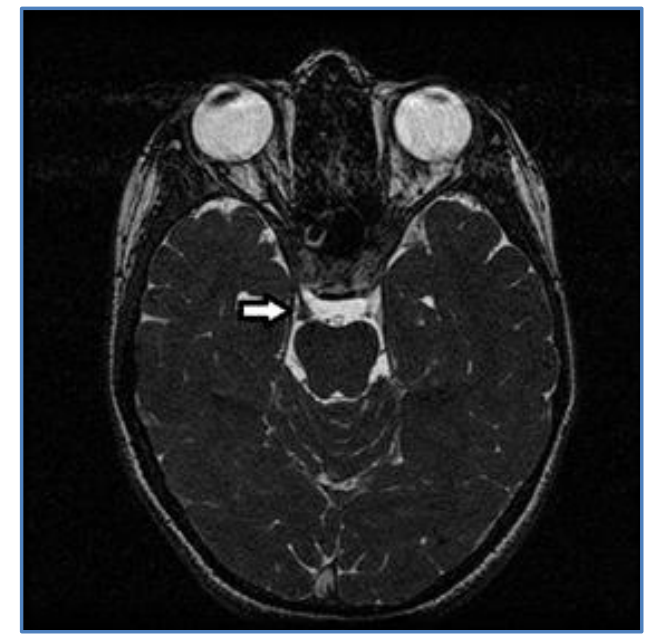

Photo 4A: Non-Contrast MRI Image

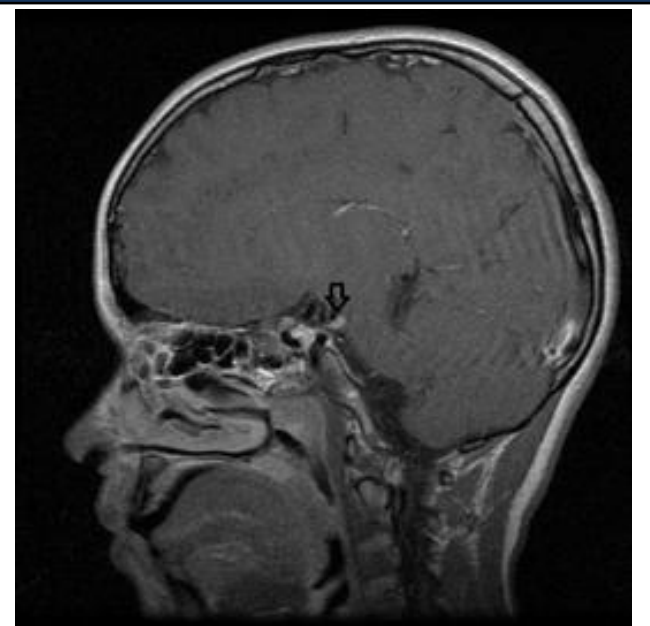

Photo 4C: T1 W Fat Saturated Sagittal View

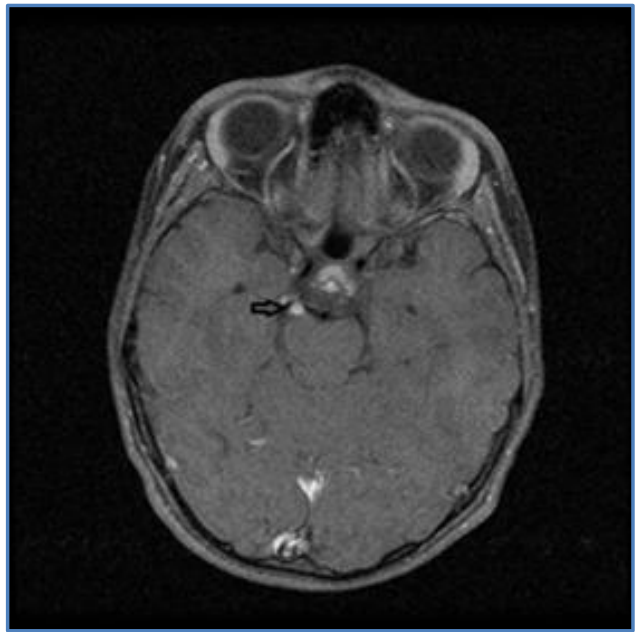

Photo 4B: T1 W Fat Saturated Axial View

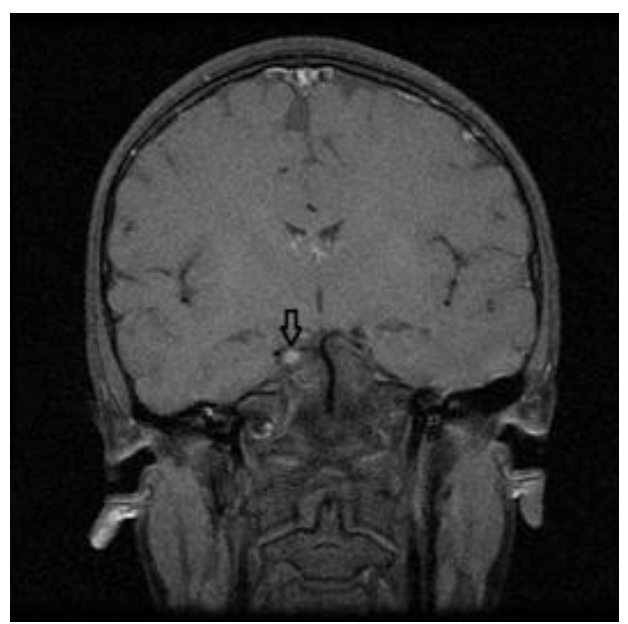

Photo 4D: T1 W Fat Saturated Coronal View

PHOTO 4: a, b, c, d. There is an approx. $7.5 \times 5.1 \times 4.8$ (AP x T x CC) mm sized lesion is noted along the long axis of the proximal most part of cisternal segment of right oculomotor nerve. The lesion is homogenous isointense to grey matter on T1 and T2W1. The lesion is seen to abut the right PCA and the midbrain on the right side. The lesion shows intense homogenous enhancement on post contrast (gadollium) study, arrows depicting the site of lesion. 


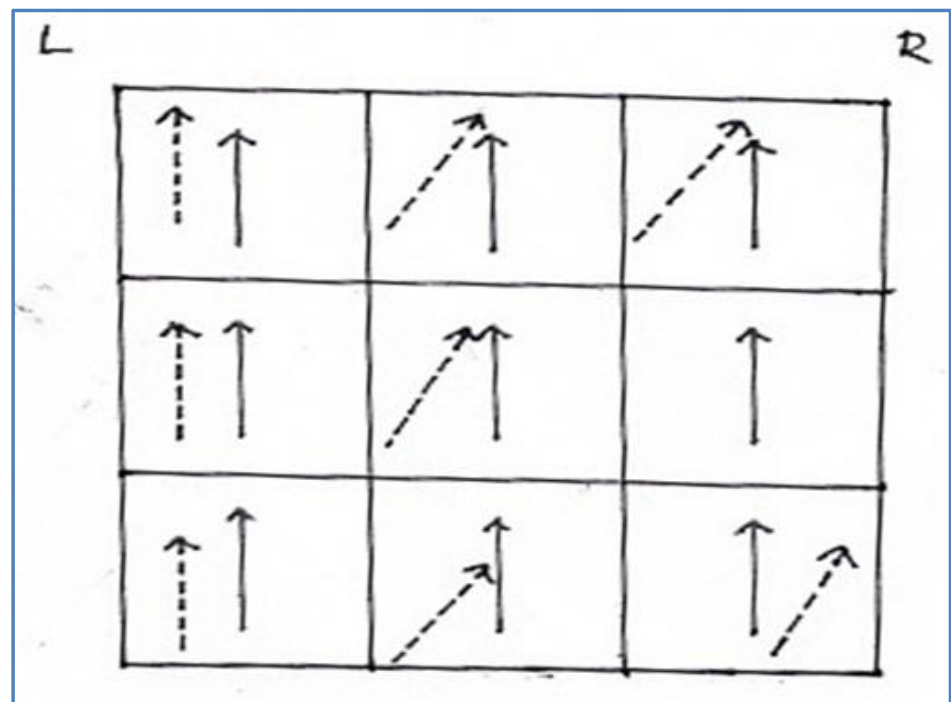

Photo 5: Diplopia chart showing right sided isolated oculomotor nerve paralysis

(Patient's view) showing binocular heteronymous crossed diplopia with false image higher with upper end tilted towards paralyzed side. view).

PHOTO 5: Diplopia chart showing right sided isolated oculomotor nerve paralysis (Patient's

Showing binocular heteronymous crossed diplopia with false image higher with upper end tilted towards paralyzed side

\section{REFERENCES:}

1. Chewning RH, Sasson AD, Jordan LC, Tamargo RJ, Gailloud P. Acute third cranial nerve palsy from a third cranial nerve schwannoma presenting as a saccular aneurysm on threedimensional computed tomography angiography: Case illustration. J Neurosurg 2008; 108: 1037.

2. Asaoka K, Sawamura Y, Murai H, Satoh M. Schwannoma of the oculomotor nerve: A case report with consideration of the surgical treatment. Neurosurgery 1999; 45:630-4.

3. Katoh M, Kawamoto T, Ohnishi K, Sawamura Y, Abe H. Asymptomatic schwannoma of the oculomotor nerve: Case report. J Clin Neurosci 2000; 7:458-60.

4. Netuka D, Benes V. Oculomotor nerve schwannoma. Br J Neurosurg 2003; 17:168-73.

5. Muhammad SS, Muhammad Ei, Khalid NC, Asad A. A child with intra-orbital oculomotor nerve schwannoma without neurofibromatosis. Can J Neurol Sci 2008; 35:528-30.

6. Carlow TJ. Oculomotor ophthalmoplegic migraine: Is it really migraine? J Neuro-Ophthalmol 2002; 22:215-21.

7. Shan-Shan Yang, Zhao-Jian Li, Xia Liu BS, Ying Li, Shi-Fang Li, Hong-Di Zhang. Pediatric Isolated Oculomotor Nerve Schwannoma: A New Case Report and Literature Review. Paediatric Neurology 2013; 48:321-324.

8. Sener RN. Malignant oculomotor schwannoma: Diffusion MR imaging. J Neuroradiol 2006; $33: 270-272$. 
9. Bejjani GK, Duong DH, Kalamarides M, Ziyal I, Sullivan BJ. Cerebral vasospasm after tumour resection. A case report. Neurochirurgie 1997; 43:164-168.

10. Mariniello G, Horvat A, Dolenc VV. En bloc resection of an intracavernous oculomotor nerve schwannoma and grafting of the oculomotor nerve with sural nerve. Case report and review of the literature. J Neurosurg 1999; 91:1045-1049.

11. Kozic D, Nagulic M, Ostojic J, et al. Malignant peripheral nerve sheath tumor of the oculomotor nerve. Acta Radiol 2006; 47:595-598.

12. Leunda G, Vaquero J, Cabezudo J, Garcia-Uria J, Bravo G. Schwannoma of the oculomotor nerves. Report of four cases. J Neurosurg 1982; 57:563-565.

13. Murakami T, Funatsuka $M$, Komine $M$, et al. Oculomotor nerve schwannoma mimicking ophthalmoplegic migraine. Neuropediatrics 2005; 36:395-398.

14. Netuka D, Benes V. Oculomotor nerve schwannoma. Br J Neurosurg 2003; 17:168-173.

15. Niazi W, Boggan JE. Schwannoma of extraocular nerves: survey of literature and case report of an isolated third nerve schwannoma. Skull Base Surg 1994; 4:219-226.

16. Bisdorff AR, Wildanger G. Oculomotor nerve schwannoma mimicking ophthalmoplegic migraine. Cephalalgia 2006; 26:1157-1159.

17. Kansu T, Ozcan OE, Ozdirim E, Onol B, Gurcay O. Neurinoma of the oculomotor nerve. Case report. J Clin Neuro Ophthalmol 1982; 2:271-277.

\section{AUTHORS:}

1. Sundip Shenoy

2. Anitha S. Maiya

3. R. Jayaram

4. Anyatama Chakravarty

5. Basavaraj Zalaki

\section{PARTICULARS OF CONTRIBUTORS:}

1. Associate Professor, Department of Ophthalmology, Adichunchanagiri Institute of Medical Sciences.

2. Assistant Professor, Department of Ophthalmology, Adichunchanagiri Institute of Medical Sciences.

3. Professor, Department of Ophthalmology, Adichunchanagiri Institute of Medical Sciences.
4. Resident, Department of Ophthalmology, Adichunchanagiri Institute of Medical Sciences.

5. Resident, Department of Ophthalmology, Adichunchanagiri Institute of Medical Sciences.

\section{NAME ADDRESS EMAIL ID OF THE CORRESPONDING AUTHOR:}

Dr. Sundip Shenoy,

FF-1, \# 44/2, Madhav Residency,

Dollar Scheme, Nandini Layout,

Bangalore - 560096.

E-mail: drsundipvision@yahoo.com

Date of Submission: 16/01/2014.

Date of Peer Review: 17/01/2014.

Date of Acceptance: 27/01/2014.

Date of Publishing: 04/02/2014. 